\title{
The Invocation of the Exception of Non-Performance: \\ A Case-Study on the Role and Application of General Principles of International Law of Contractual Origin
}

\author{
Filippo Fontanelli*
}

\section{Keywords}

Exception of non-performance, General principles of international law, International Court of Justice, Law of treaties, Law of responsibility

\section{Introduction}

In a recent cartoon from the New Yorker, a lawyer is seen standing before a judge, his arms stretched, making him a passionate request: "Can we, just for a moment, Your Honor, ignore the facts?"1 This cartoon brilliantly encapsulates the centrifugal force of legal argumentation, which at times causes otherwise consummate professionals to lose touch with the facts in which disputes should be firmly rooted.

Admittedly, this article attempts a similar exercise, but deliberately. Its purpose is to analyse the technicalities of an objection raised in a recent proceeding before the International Court of Justice (ICJ), as if the facts

\footnotetext{
Lecturer in Law, School of Law, University of Surrey. This article is the result of autonomous research carried out entirely after the author's traineeship at the ICJ, and none of the views expressed herein are attributable to the Court or its staff. A preliminary version was presented in Paris at the conference "Is the centre of international law reasserting itself?" on 14 February 2012. Any remaining errors are attributable solely to the author.

1 See <http://www.condenaststore.com/-sp/Can-we-just-for-a-moment-Your-Honor-ignore -the-facts-Cartoon-Prints_i8534482_.htm> [last accessed 2 May 2012]. A framed copy of this cartoon is in the office of Judge Kenneth J. Keith of the International Court of Justice, who first showed it to me.
} 
underlying the dispute did not matter. In reality, the facts mattered so much that the Court did not feel the need to peruse this objection in anything more than a cursory fashion. This, it is submitted, was unfortunate, because it prevented the judges from clarifying some basic elements of the system of sources of international law.

In December 2011, the ICJ delivered the judgment in the Application of the Interim Accord of 13 September 1995 case, ${ }^{2}$ finding that Greece had objected to the former Yugoslavian Republic of Macedonia's (FYROM) accession to NATO and, by so doing, had violated a provision of the Interim Accord (IA) concluded between the two states in 1995. ${ }^{3}$ Greece then challenged FYROM's claims, contending that no such objection had occurred within the meaning of the treaty, and that in any case the wrongfulness of that conduct was precluded by FYROM's previous breaches of the IA. ${ }^{4}$

In order to strengthen this second defense, Greece listed all of FYROM's actions that allegedly constituted a breach of the $\mathrm{IA}^{5}$ which predated Greece's own wrongful conduct (i.e. Greece actively preventing NATO from extending to FYROM an invitation to NATO's April 2008 summit). In Greece's view, these violations entitled it to withhold-in part-performance of the IA: (a) under Article $60^{6}$ of the Vienna Convention on the Law of Treaties ${ }^{7}$ (VCLT); (b) under the discipline of state responsibility; ${ }^{8}$ or (c) in application of the exception of non-performance, whereby performance need not be extended in light of a counterpart's default: inadimpleti contractus non est adimplendum.

This article focuses exclusively on the exceptio defense and uses it as a pretext to observe the process of identification, interpretation and application of general principles of international law drawn from domestic civil law doctrines.

2 Application of the Interim Accord of 13 September 1995 (the former Yugoslav Republic of Macedonia $v$ Greece), Judgment, 5 December 2011 (not yet published), available at <http://www.icjcij.org/docket/files/142/16827.pdf> [last accessed 15 May 2012].

31891 UNTS 4, Art. 11: "[Greece] agrees not to object to the application by or the membership of [the FYROM] in international, multilateral and regional organizations and institutions of which [Greece] is a member [...]."

${ }^{4}$ Greece also advanced several preliminary jurisdictional objections. On this judgment, see F. Fontanelli and E. Bjorge's comment: (2012) 61 ICLQ (forthcoming).

5 Namely FYROM's failure to conduct the negotiations about the name dispute in good faith (IA Art. 5(1)), its interference in Greece's internal affairs (IA Art. 5(2)), its tolerance of hostile activities performed by State entities and the use of the symbol of the Sun of Vergina and of other cultural symbols belonging to Greek cultural heritage (IA Art. 7(1), (2) and (3)).

${ }^{6}$ Governing the termination or suspension of a treaty as a consequence of its breach.

${ }^{7} 1969$ Vienna Convention on the Law of Treaties, 1155 UNTS 331.

8 As codified in the ILC's Articles on the Responsibility of States for Internationally Wrongful Acts, 2001/II(2) ILC Ybk, 31. See in particular Arts. 22, 49-53 on countermeasures. 
In the case at hand, the ICJ rejected the exception on the facts, noting that Greece could not prove any of the alleged breaches by FYROM, except for a single minor one. ${ }^{9}$ Accordingly, the exception could not apply in any event, and the ICJ did not bother to establish whether it actually exists as a principle of the law of treaties or of the law of responsibility, and what its real content is.

The superficial treatment of the exceptio, dictated by judicial economy, was met with disappointment by Judges Simma and Bennouna. They devoted a Separate Opinion and a Declaration respectively to this point, lamenting that the Court had relied on the reconstruction of the principle proposed by Greece and shied away from an autonomous review of the exception ${ }^{10}$ under the cover of iura novit curia. This exercise, however, was ultimately unnecessary to resolve the relevant dispute, in which the exceptio seemed to play the ungrateful role of the defendant's old college try. ${ }^{11}$

This article offers a brief introduction to the exceptio as a legal concept (II), and considers its possible inclusion among the general principles of international law (III). Assuming that this inclusion is warranted, the international norms that govern the same matters touched by such principle are observed, jointly (IV) and severally (V), to assess whether there actually is a gap in the normative fabric of international law to be filled by the exceptio. In the conclusion (VI), it is argued that this step-by-step analysis, if performed by the Court, would have not changed the outcome of the case, but could have helped to further elucidate the role of general principles in international law.

\section{The exceptio, historical origins and content}

The exceptio non adimpleti contractus is a principle governing the regime of the mutual obligations between the parties to the same contract. It bestows on a subject (A), at once debtor and creditor in the framework of the same agreement, the power to paralyze the other party's (B) request of performance subsequent

\footnotetext{
9 Namely, the use of the Sun of Vergina on the uniforms of a regiment of FYROM's army, which was disbanded in 2004.

${ }^{10}$ Application of the Interim Accord, supra note 2, para. 161; para. 6 (Judge Simma); at 1 (Judge Bennouna). A similar reasoning was used to rebut Namibia's invocation of the principle of acquisitive prescription: "the conditions cited by Namibia itself are not satisfied in this case": Kasikili/Sedudu Island (Botswana/Namibia), Judgment, ICJ Reports 1999, p. 1045, at 1105, para. 97.

${ }^{11}$ From Babe Ruth's Own Book of Baseball (G.P. Putnam's Son, 1928), at 301: “giving it the old college try' [means] ... making strenuous effort to field a ball that obviously cannot be handled". See Application of the Interim Accord, supra note 2, para. 3 (Judge Simma).
} 
to B's own non-performance. Performance by A, therefore, can be withheld, at least temporarily, to prevent the asymmetric and unfair execution of the agreement. When one of the parties defaults on his or her obligation, the exception freezes the status of mutual non-performance, restoring reciprocity.

Although the kernel of this principle is a heritage of Roman law traceable back to the discipline of the sale and purchase of goods (emptio-venditio), ${ }^{12}$ its full formulation is a medieval development. ${ }^{13}$ Its rationale is somewhat ambivalent. On the one hand, it aims at preventing the unfair judicial sanction that would otherwise be levied against the aggrieved party who refuses to discharge his obligation (procedural exception). On the other, the exceptio may be seen as a particular principle of contractual law, reflecting the idea that the contractual synallagma ( $\sigma \nu \nu \dot{\alpha} \lambda \lambda \alpha \gamma \mu \alpha)$ is essential, and that, as a consequence, the validity of contractual obligations is inherently dependant on reciprocity (condition of validity).

The first interpretation (procedural exception) has proved more convincing over time: it is accepted that the exceptio entitles the aggrieved party to withhold performance when the other party has not performed without incurring the normal legal consequences, and can be raised in court to avoid an unfair finding of liability. However, the exceptio also appears to have some substantive implications on the obligations of the parties in reciprocal agreements, as posited by the German scholarship, in particular after the publication of Bechmann's 'Der Kaufnach gemeinem Recht, I, Geschichte des Kaufs im römischen Recht. ${ }^{14}$ In this seminal work, Bechmann perused the concept of

${ }^{12}$ See P. O'Neill, and N. Salam, 'Is the Exceptio Non Adimpleti Contractus Part of the New Lex Mercatoria?', in E. Gaillard (ed), Transnational Rules in International Commercial Arbitration (ICC, 1993), 147, at 152.

${ }^{13}$ See G. Scaduto, 'L'exceptio non adimpleti contractus' nel diritto civile italiano', (1921) VII Annali dell'Università di Palermo 79, attributing to Bartolo da Sassoferrato the comment of Justinian's Digest [D. 19.1.13.8] that reads: 'contractu ultro citroque obligatorio non potest effectualiter agi, nisi ab eo qui effectualiter totum contractum ex parte sua impleverit' [only that who performed it effectively in its entirety can successfully invoke a contract producing reciprocal obligations]. According to others, this formula comes from a passage of the Digest [Code 2.3.21], which includes the expression 'Nec adversario tuo transactione uti concendendum est, nisi ea, quae placita sunt, adimplere paratus sit' [you shall not let your counter-party take advantage of a transaction, unless he is ready to perform what is agreed] that was commented as follows (referring to certain specific cases): 'non es[t] servanda[] fide[s] non servanti' [one must not be faithful to that who is unfaithful]: see e.g. R. Cassin, De l'exception tirée de l'inexécution dans les rapports synallagmatiques [exceptio non adimpleti contractus] et de ses relations avec le droit de rétention, la compensation et la résolution (Paris, 1914), at 1 (note 1) and G. Persico, L'eccezione di inadempimento (Giuffrè, 1955), at 2 (note 2).

${ }^{14}$ A. Bechmann, Der Kauf nach gemeinem Recht, I, Geschichte des Kaufs im römischen Recht 
synallagmaticity, and distinguished between its implications at the moment of formation of the obligation and at that of its performance (the exceptio affecting the latter). However, this elaboration has never led to the conclusion that the execution of contractual obligations is conditioned de iure upon the performance of the "reciprocal" counter-obligations. As noted by V. Arangio Ruiz, the exceptio can be considered a trend, a benchmark of evaluation of the parties' good faith in the execution of the agreement, rather than an absolute principle of interdependence of contractual obligations. ${ }^{15}$

To sum up, in modern legal practice, the exception of non-performance can be characterised as follows: a refusal to perform by one party which would be objectively wrongful under the terms of the contract may be lawful in light of the previous conduct of the other party. The power to avail oneself of the exceptio non adimpleti contractus boils down to the possibility to adopt conduct in violation of the contractual commitment and to invoke the other party's non-performance together with the evidence proving it as a justification for non-performance. ${ }^{16}$ It is reasonable to rely on the findings of those who have performed a full comparative analysis, and submit that this principle of the law of contracts is indeed traceable in most modern legal orders. ${ }^{17}$

\section{The exceptio as a general principle of the civilised nations}

The application of private law principles to matters of international law, and in particular the scope of the analogy between contracts and treaties has been

(Erlangen, 1876).

${ }^{15}$ V. Arangio Ruiz, La compravendita in diritto romano (Jovene, 1956), at 214ff, noting that in Roman law "there was a trend to evaluate the position of both parties as a whole, because the obligations entered by each party were the cause for those entered by the other one ... This trend, however, had to be harmonized with the rules of procedure, as well as other needs of equity and economic nature".

${ }^{16}$ S. Pugliatti, 'Eccezione (teoria generale)' in Enciclopedia del Diritto (Giuffrè, 1965), at 151.

${ }^{17}$ Application of the Interim Accord, supra note 2, para. 12 (Judge Simma). J. Crawford and S. Olleson underscore the divide between civil and common law systems in this respect: "The Exception of Non-performance: Links between the Law of Treaties and the Law of State Responsibility', (2001) 21 Austr YIL 55. See also O'Neill and Salam, supra note 12, at 159, examining whether the exceptio is diffused enough to be a general principle of law and form part of lex mercatoria. The test used is similar to that implied under Art. 38(1)(c) of the ICJ Statute: ibid., at 151 ("the bottom line in ascertaining general principles seems to be whether the rules of various legal systems, although differently formulated, nevertheless produce the same result in gauging whether a rule is a general principle”). 
discussed extensively. As it was once said, "the Law of Nations is but private law 'writ large", ${ }^{18}$ insofar as it applies to states the legal ideas applicable to relations between individuals. This cannot mean that every rule of private law, by its own existence, deserves to be transplanted to the international level "lock, stock and barrel": the judge must treat them as a reminder of the "policies and principles" that ought to be applied in every legal order, ${ }^{19}$ a repository of the ratio scripta. ${ }^{20}$ This process of abstraction, however, might result in formulating international norms with little or no substance, ${ }^{21}$ tautologies whose only weight seemingly resides in their Latin garb. ${ }^{22}$

However, importing principles from domestic systems seemed at one time inevitable due to the perceived insufficiency of the formal international sources combined (treaties and customs). Indeed, the Advisory Committee of Jurists that in 1920 drafted the Statute of the Permanent Court of International Justice $^{23}$ adopted Baron Descamps' proposal to include general principles among the sources of law applicable by the Court with a view to preventing rulings of non liquet. ${ }^{24}$ This source, resorted to as an incarnation of natural law, and then "re-construed as an emanation of domestic traditions" 25 to meet the approval of the positivist members of the Committee, ${ }^{26}$ was accepted even by those members who fiercely objected to giving the new Court any law-creating power (such as the American Elihu Root). Indeed, it was clarified that applying a general principle would be tantamount to "merely br[inging] to

${ }_{18}$ T. E. Holland, Studies in International Law and Diplomacy (Clarendon, 1898), at 152. This view was in turn supported by H. Lauterpacht, Private Law Sources and Analogies of International Law (Longmans, Green \& Co, Ltd, 1927), at 81.

${ }^{19}$ International Status of South-West Africa, Advisory Opinion, ICJ Reports 1950, p. 128, at 148 (Judge McNair, dissenting).

${ }^{20}$ Barcelona Traction, Light and Power Company, Limited (Belgium v Spain), Second Phase, Judgment, ICJ Reports 1970, p. 6, at 66, para. 5 (Judge Fitzmaurice). See also France's pleadings in Phosphates in Morocco (Italy v France), PCIJ Reports Series C No 85, at 1060-1.

${ }^{21}$ Weil, (1992/VI) 237 Hague Recueil 9, at 146: "D'une certaine manière, le processus d'abstraction-généralisation est autodestructeur."

${ }^{22}$ O. Schachter, International Law in Theory and Practice (Martinus Nijhoff, 1991), at 54.

${ }^{23}$ Upon mandate conferred by the Council of the League of Nations, acting under Art. 14 of the Covenant of the League of Nations, relating to the establishment of the PCIJ.

${ }^{24}$ For a detailed account of the travaux préparatoires of Art. 38 of PCIJ-ICJ Statute, see A. Pellet, 'Article 38', in A. Zimmermann, C. Tomuschat and K. Oellers-Frahm (eds), The Statute of the International Court of Justice: a Commentary (OUP, 2006), 677, at 684ff; B. Cheng, General Principles of Law as Applied by International Courts and Tribunals (Grotius, 1953), at 6-22.

${ }^{25} \mathrm{~J}$. D'Aspremont, Formalism and the Sources of International Law: A Theory of the Ascertainment of Legal Rules (OUP, 2012), at 171.

${ }^{26}$ On this compromise, see in particular PCIJ, Procès-Verbaux of the Proceedings of the Advisory Committee of Jurists, 16 June to 24 July 1920 (Van Langenhuysen Brothers, 1920), at 335, 345. 
light a latent rule" 27 among those already accepted in foro domestico, ${ }^{28}$ and would only intervene to fill the a lacuna of positive law. ${ }^{29}$ As Hersch Lauterpacht noted, examining in detail the various theories on the use of Roman and private law principles in the practice of international law:

\begin{abstract}
When, in international disputes, rules of general jurisprudence are referred to, what is meant is that not a rule of one particular system of private law is to be applied, but only such a rule-usually a private law rule-as has gained recognition by the general body of civilized nations. This is so for the simple reason that international law has not, in the particular sphere, developed any rules on its own. In fact, there would be no need to have recourse to general jurisprudence, if there were an international rule ready at hand. ${ }^{30}$
\end{abstract}

This approach is premised on the view that international law is a complete system, ${ }^{31}$ and that accordingly, in the presence of a gap, the inevitable course of action is to deploy general principles, rather than acknowledging that certain acts or facts are not governed by any norm. ${ }^{32}$

${ }^{27} \mathrm{Ibid}$., at 346 (emphasis in the original).

${ }^{28}$ This expression is used by Lord Phillimore, ibid., 335, who provides an illustrative list: "certain principles of procedure, the principle of good faith, and the principle of res judicata".

${ }^{29}$ As Schwarzenberger puts it in his Foreword to Cheng's great work, the drafters of the Statute: "enabled the Court to replenish, without subterfuge, the rules of international law by principles of law tested within the shelter of more mature and closely integrated systems": Cheng, supra note 24 , at xi.

${ }^{30}$ H. Lauterpacht, 'Private Law Sources and Analogies of International Law', in E. Lauterpacht (ed), International Law: Being the Collected Papers of Hersch Lauterpacht (CUP, 1975), Vol II, 173, at 206 (emphasis added). This work is a revision of the first chapter of Lauterpacht's earlier dissertation, supra note 18.

${ }^{31}$ Conclusions of the work of the Study Group on the Fragmentation of International Law, 2006/II(2) ILC Ybk (forthcoming), para. 1. Also published as M. Koskenniemi (ed), Fragmentation of International Law: Difficulties Arising from the Diversification and Expansion of International Law-Report of the Study Group of the International Law Commission (Erik Castrén Institute, 2007), at 263, para. 14(1).

${ }^{32} \mathrm{~A}$ discussion of this assumption is outside the scope of the present article, if only because it is argued here not that lacunx need no filling, but that there is no lacuna for the exceptio to fill. But see H. Lauterpacht, 'Some Observations on the Prohibition of "Non Liquet" and the Completeness of the Legal Order', in E. Lauterpacht, supra note 30, at 213 (previously published in 1958) and J. Stone's rebuttal in 'Non Liquet and the Function of Law in the International Community', (1959) 35 BYIL 124. For a recent work, see J. Kammerhofer, 'Gaps, the Nuclear Weapons Advisory Opinion and the Structure of International Legal Argument between Theory and Practice', (2009) 80 BYIL 333. 
The question then arises of whether the exceptio can be regarded as one of the general principles of law that, according to this intellectual framework, can be transposed to the international sphere. As it was noted above, the exceptio appears to find expression in the majority of domestic legal systems. However, in and of itself, the exceptio is a norm of contract law or, at best, a norm of the law of obligations. It cannot be said that it is a universal principle of law per $s e$, though it certainly embodies the more fundamental principles of fairness, equity and good faith that are ingrained in every field of law. However, such broad norms operate in combination with other principles which are proper to each area: for example, in international law the principle pacta sunt servanda has a fundamental role as it ensures the stability and the maintenance of the system of international relations at large.

This tension surfaces even in Grotius' teaching. First, he notes that "servanda[ ] autem fide[s] etiam perfidis" (Faith is to be kept even with those that are perfidious), ${ }^{33}$ but then he rushes to clarify that the strict connection between the mutual obligations of the same instrument can excuse the aggrieved party who refuses to perform. ${ }^{34}$

In fact, the question is otiose: far below the heaven of principles exist special rules-examined in the following paragraphs-that flesh out the exceptio and dispel the possibility of invoking its ethereal form in the field of interstate treaty relations.

\section{The leges speciales of state responsibility and law of the treaties}

Whether or not the exceptio may be regarded as a general principle of law, one should be mindful of the fact that the temptation to postulate principles of law elaborating on general values should be resisted at the international level:

\footnotetext{
${ }^{33}$ H. Grotius, De Jure Belli ac Pacis (1625, tr. J. Morrice 1738 : repr. Liberty Fund, 2005), bk. III, ch. XIX, para. xiii (at 1545), modeled upon a passage from St. Ambrose, De Officiis 1, 29. Along the same lines, see G. Del Vecchio, 'Truth and Untruth in Morals and Law', (1953) 39 Iowa LR 16, at 57: 'it is not just that the law always permit one to respond to unlawfulness with unlawfulness (because it would then cease to be such).' On the limits of reciprocity in international law, see A. Paulus, 'Reciprocity Revisited', in U. Fastenrath et al. (eds), From Bilateralism to Community Interest: Essays in Honour of Bruno Simma (OUP, 2011), at 113.

${ }^{34}$ Grotius, supra note 33, bk. III, ch. XIX, para. xiv (at 1546-7). Another passage is quoted in Application of the Interim Accord, supra note 2, para. 15 (Judge Simma).
} 
Le travail théorique d'abstraction positive, par lequel, dans le droit privé, l'interprète parvient à remonter de la comparaison et du groupement des règles particulières à la construction des grandes catégories du droit et à la détermination des règles générales du système, n'est pas possible dans le droit international. ${ }^{35}$

In light of these remarks, the rule of thumb in the application of general principles is clear: they apply directly when there is no conventional or customary rule of international law governing on a matter. The characteristic pliability of such principles to an applicable lex specialis was confirmed by the International Law Commission's (ILC) Fragmentation Study:

The parties are taken to refer to customary international law and general principles of law for all questions which the treaty does not itself resolve in express terms. ${ }^{36}$

The application of lex specialis derogat legi generali is especially appropriate when, like in the case of the exception of non-performance, a general principle would only be capable of application by analogy (between contractual and treaty obligations). The general values of good faith and fairness that the exceptio embodies at the domestic level are hardly such as to fill the gaps of the normative regimes of international law in fields like treaty law or state responsibility. In fact, one should not confuse the application of general principles with their use as an interpretive support ${ }^{37}$ : whereas it is certainly appropriate and desirable that general principles be used to facilitate the interpretation ${ }^{38}$ of the VCLT and

${ }^{35}$ Cavaglieri, (1929/I) 26 Hague Recueil 311, at 322, quoted in Strupp, (1930/III) 33 Hague Recueil $351,454-5$.

${ }^{36}$ ILC Conclusions, supra note 31, para. (19)(a); Koskenniemi, supra note 31, 270, para. 14(19)(a). See also the Full Report of the ILC Study Group, UN Doc. A/CN.4/L.682 (2006), paras. 462 ff; Koskenniemi, supra note 31, at 233ff, paras. 462ff.

${ }^{37} \mathrm{On}$ this fundamental distinction, often overlooked in the literature and jurisprudence, see A. Gourgourinis, 'The Distinction between Interpretation and Application of Norms in International Adjudication', (2011) 2 JIDS 31.

${ }^{38}$ See e.g. Amoco International Finance Corporation v Iran (1987-II) 15 Iran-US CTR 189, at 222; in Oil Platforms (Islamic Republic of Iran v United States of America), Judgment, ICJ Reports 2003, p. 161, the ICJ used the principle prohibiting the use of force to interpret the standard of necessity in the US/Iran Treaty of Amity. See J. Kurtz, 'Adjudging the Exceptional at International Law: Security, Public Order and Financial Crisis' (2008) NYU IILJ Working Paper 2008/06, at 35-7, and E. Jouannet, 'Le juge international face aux problèmes de l'incohérence et d'instabilité de droit international. Quelques réflexions à propos de l'arrêt CIJ du 6.11.2003', (2004) 108 RGDIP 917, at 933, 936. 
of the ILC Articles on the Responsibility of States for Internationally Wrongful Acts (ARSIWA), they normally cannot find direct application in these matters. ${ }^{39}$

At this point, a reference to the dictum of the Georges Pinson tribunal is almost mandatory:

Toute convention internationale doit être réputée se référer tacitement aux principes généraux du droit international pour toutes les questions qu'elle ne résout pas elle-même en termes exprès ou autrement. $^{40}$

In other words, the general principle of the exception (better, the general principle of fairness expressed therein) could only apply directly, as Greece contended, if there were a normative gap in the rules of international law applicable between the parties. ${ }^{41}$ As noted above, the exceptio principle governs the powers of one party facing another party's default on his contractual duties. In the operative part, the principle justifies the first party's withholding of performance, as a lawful response to the other party's wrongdoing. The contract remains in force. The factual scenario engaging the application of the principle, therefore, is the non-performance of an obligation inscribed in a framework of reciprocal obligations. If no existing treaty or customary rule of international law could apply to a similar factual hypothesis, as transplanted in the area of treaty law, the exceptio principle could apply directly.

In fact, it appears that this matter is thoroughly regulated by rules of treaty law contained in the VCLT and rules of state responsibility codified by the ILC that are of recognized customary nature. In particular, VCLT Article 60 regulates the case of unilateral suspension of a bilateral treaty: if it is in response to a material breach, suspension is justified, otherwise it is wrongful. If the wrongful suspension results itself in a material breach of the treaty, it entitles the

${ }^{39}$ On general principles as the North Star in the interpretation of positive rules, see generally Pulp Mills on the River Uruguay (Argentina v Uruguay), Judgment, ICJ Reports 2010, p. 14, passim (Judge Cançado Trindade).

${ }^{40}$ Georges Pinson (France/United Mexican States), (1928) 5 RIAA 327, at 422. More recently, see Dispute Concerning Access to Information under Article 9 of the OSPAR Convention (Ireland $v$ United Kingdom), (2003) 126 ILR 334, at 364, para. 84.

${ }^{41}$ See Pellet, supra note 24, at 780: "[principles] are subsidiary in the sense that the Court will usually only resort to them for filling a gap in the treaty or customary rules available to settle a particular dispute, and, what is even more apparent, will decline to invoke them when such other rules exist". For a similar statement, see Eastern Extension, Australasia and China Telegraph Company, Ltd (Great Britain v United States), (1923) 6 RIAA 112, at 114: "the function of jurisprudence is to resolve the conflict of opposing rights and interests by applying, in default of any specific provisions of law, the corollaries of general principles". 
other party to suspend or terminate a treaty in whole or in part. The ARSIWA also govern cases of breach of international obligations in Articles 22 and 49 to 53 , providing that the injured state is entitled to take counter-measures, subject to certain conditions, and that those counter-measures are to be considered lawful, even if they would have otherwise constituted a wrongful act.

It is therefore difficult to understand why recourse to the general principle should be had at all, given that there are applicable rules governing the same factual hypotheses and attaching thereto an array of legal consequences (regarding the validity of the treaty, the modality of the reactions to a breach and the conditions for a party to take such reactions lawfully). Importantly, these rules are modeled precisely on the values that are at the basis of the exceptio (reciprocity; good faith; even-handedness; ex iniuria ius non oritur; non-wrongfulness of non-performance due to impossibility; and even self-defence, to an extent): it cannot be said that application of the rules of the VCLT or the ARSIWA frustrates the purpose of these general principles. ${ }^{42}$

\section{The regimes of treaty obligations and state responsibility, considered separately}

To examine the issue further, one might distinguish between the two regimes: one pertaining to the operation of treaty obligations (the VCLT) and the other to the responsibility of states (the ARSIWA). Since these two regimes are concerned with different matters, they might apply at the same time to the same set of facts/acts, as VCLT Article $73^{43}$ and paragraph 8 of the Preamble thereof suggest, and as ARSIWA Article 56 expressly envisages. ${ }^{44}$

In the Gabčkovo-Nagymaros case, the Court acknowledged the different functions of the two regimes:

\footnotetext{
${ }^{42}$ For an erudite account of good faith as a regulative element into the interpretation of consensual inter-state engagements, see Schwarzenberger, (1955/I) 87 Hague Recueil 191, at 290-326.

${ }^{43}$ According to which the Convention "shall not prejudge any question that may arise in regard to a treaty ... from the international responsibility of a State".

${ }^{44}$ See Clarification (3) to ARSIWA Art. 56, ILC Commentary, supra note 8, at 141: "A second function served by article 56 is to make it clear that the present articles are not concerned with any legal effects of a breach of an international obligation which do not flow from the rules of State responsibility, but stem from the law of treaties or other areas of law. Examples include ... the termination of the international obligation violated in the case of a material breach of a bilateral treaty".
} 
A determination of whether a convention is or is not in force, and whether it has or has not been properly suspended or denounced, is to be made pursuant to the law of treaties. On the other hand, an evaluation of the extent to which the suspension or denunciation of a convention, seen as incompatible with the law of treaties, involves the responsibility of the State which proceeded to it, is to be made under the law of State responsibility.

Thus the [VCLT] confines itself to defining in a limitative manner the conditions in which a treaty may lawfully be denounced or suspended; while the effects of a denunciation or suspension seen as not meeting those conditions are, on the contrary, expressly excluded from the scope of the Convention by operation of Article 73. It is moreover well established that, when a State has committed an internationally wrongful act, its international responsibility is likely to be involved whatever the nature of the obligation it has failed to respect. ${ }^{45}$

In light of this division, it is necessary to inquire whether the general principle could apply directly to fill a regulatory gap of either regime (rather than of their combined normative coverage). As indicated above, the general principle of the exceptio is amenable to both regimes, although it has more to do with the legality of the non-performance of the 'reacting' party (an issue of responsibility) than with the fate of the contractual obligations (which, in principle, are still in place even after the non-performance by both parties, since suspension does not equal termination).

\subsection{State responsibility}

As a set of secondary rules in a particular field of international law, the ARSIWA are exhaustive, since they cover every instance of breach, clarify the courses of action available to the non-breaching party, and specify their conditions. They are not concerned with the destiny of the obligations involved. FYROM's alleged violations of the IA fall well within the ARSIWA regime, and if Greece

\footnotetext{
${ }^{45}$ Gabčikovo-Nagymaros Project (Hungary/Slovakia), Judgment, ICJ Reports 1997, p. 7, at 38-9, paras. 47-8. The Court refers to the cases Interpretation of Peace Treaties with Bulgaria, Hungary and Romania, Second Phase, Advisory Opinion, ICJ Reports 1950, p. 221, at 228; and to Art. 17 of the Draft Articles on the Responsibility of States for Internationally Wrongful Acts provisionally adopted by the International Law Commission on first reading (preceding the ARSIWA): 1980/II(2) ILC Ybk, at 32.
} 
wanted to invoke the regime so as not to incur responsibility for breaching Article 11 of the IA, it should have turned to ARSIWA Articles 22 and 49 precluding the wrongfulness of counter-measures.

In his Separate Opinion, Judge Simma was of the view that "State responsibility has nothing to do with the maxim inadimplenti non est adimplendum". ${ }^{46}$ This position is based on a narrow focus on "the synallagma" between the respective obligations of the parties on which the exceptio is based (a requirement that is irrelevant in the regime of counter-measures), and on the assumption that for all purposes the withholding of one's performance under the exceptio is tantamount to the suspension of a treaty obligation (and therefore falls under the scope of the VCLT). To Judge Simma, counter-measures entailing a refusal to perform a bilateral treaty may look like suspension, but are not the same.

These reasons suffer from a form of petitio principii, as they assume that suspension is the international law avatar of the exceptio. This might well be the best reconstruction of the concept, but looking at how the principle operates domestically, two observations may be made. Firstly, it turns out that the exceptio is seldom dependant on the eluding link of the synallagma (are not all contracts with reciprocal obligations a form of quid pro quo, after all?), and is-ironically-more frequently reliant on a requirement of minimum gravity of the breach. Second, the exception of non-performance, in essence, relieves the aggrieved non-performing party from his or her otherwise inevitable contractual responsibility. It is therefore reasonable to accept that, mutatis mutandis, the international transubstantiation of the principle could also fall in the field of application of the circumstances precluding wrongfulness, within the realm of the law of state responsibility.

In this vein, the ILC contemplated the inclusion of the exceptio in the Articles at various stages. ${ }^{47}$ In 1992, it considered that a distinct category of counter-measures based on the exceptio (designated "reciprocal measures") "did not deserve a special treatment". ${ }^{48}$ In his Second Report, Special Rapporteur Crawford subscribed to this view and discarded the possibility of adding the exceptio to Part III of the Draft, that is, as a rule relating to the implementation of state responsibility. He cited the stability of international obligations as a prevailing concern:

The underlying problem is that a broad view of the exceptio may

\footnotetext{
${ }^{46}$ Application of the Interim Accord, supra note 2, para. 20 (Judge Simma).

${ }^{47}$ For an exhaustive account of the ILC's debate on the exceptio, see Crawford and Olleson, supra note 17.

${ }^{48}$ Report of the ILC on the work of its forty-fourth session, 1992/II(2) ILC Ybk, at 23.
} 
produce escalating non-compliance, negating for practical purposes the continuing effect of the obligation. ... [T] he justification for non-compliance with synallagmatic obligations should be resolved (a) by the law relating to the suspension or termination of those obligations (which is sufficient to deal with most problems of treaty obligations), and (b) by the law of countermeasures. ${ }^{49}$

Instead, the Rapporteur proposed to retain, as a measure precluding wrongfulness different from counter-measures, a "narrow" version of the exceptio, apparently adopted in Gabčikovo-Nagymaros. In that judgment, the Court denied Hungary's right to terminate a treaty because Czechoslovakia's relevant breach had been committed "as a result of Hungary's own prior wrongful conduct". ${ }^{50}$ The strict causal link between the prior non-performance and the subsequent (excused) one ${ }^{51}$ made this construction of the exceptio a hybrid between a counter-measure and the excuse of force majeure-hence its suggested insertion into Part I of the Draft. ${ }^{52}$ Discussion on this provision was initially postponed after the definition of the discipline on counter-measures, ${ }^{53}$ and ultimately abandoned altogether. For the purpose of the present study, suffice it to say that the "narrow" version of the exceptio, the only one which arguably could still be floating somewhere outside the ARSIWA, would have provided no help to Greece, which was certainly not prevented from complying with Article 11 of the IA "as a direct result of a prior [FYROM's] breach". ${ }^{4}$

In sum, the exception of non-performance is banned from the field of application of the ARISWA. In particular, Greece's attempt to rely on a non-codified category of reciprocal measures in the framework of the IA is

\footnotetext{
${ }^{49}$ See J. Crawford, Second Report on State Responsibility, 1999/II(1) ILC Ybk, at 79-82.

${ }^{50}$ Gabčkovo-Nagymaros Project, supra note 45, at 67, para. 110, building on the dictum of Factory at Chorzów (Germany v Poland) (Jurisdiction), Judgment, PCIJ Report Series A No 9, at 31.

${ }^{51}$ Used for instance in the 1980 UNCITRAL Convention on Contracts for the International Sale of Goods, 1489 UNTS 3, Art. 80: "A party may not rely on a failure of the other party to perform, to the extent that such failure was caused by the first party's act or omission."

52 The proposed article 30 bis read: "The wrongfulness of an act of a State not in conformity with an international obligation of that State is precluded if the State has been prevented from acting in conformity with the obligation as a direct result of a prior breach of the same or a related international obligation by another State" (emphasis added).

${ }^{53}$ See the ILC's debate on the Second Report, 1999/II(2) ILC Ybk, at 79-80.

${ }^{54}$ In his Separate Opinion, Simma leaves out this obvious aspect and strives to demonstrate the implausibility also of the "narrow" exception, living up to his declared intention to elaborate on the "exceptio's whereabouts and 'right to life", quite apart from its bearing on Greece's conduct: Application of the Interim Accord, supra note 2, para. 7 (Judge Simma). Bennouna instead stresses this aspect: ibid., 1 (Judge Bennouna).
} 
hard to square with the travaux of the ARISWA: the commissioners and the Special Rapporteur did not inadvertently leave a matter outside the regime; to the contrary, they considered the issue and expressly decided not to regulate this kind of act any differently than provided by the discipline of counter-measures. In light of this evidence, it seems unreasonable to claim that a gap exists in the law of state responsibility.

\subsection{Law of treaties}

In contrast to the ARISWA, the rules of the VCLT, which are concerned with the consequences of a breach on the treaty itself, only regulate the hypothesis of "material" breaches, in VCLT Article $60 .{ }^{55}$ The hypothesis of non-material breaches is not expressly mentioned in the VCLT. However, this omission could hardly be seen as a gap: rather, it is an instance of the maxim ubi lex voluit dixit, ubi noluit tacuit (if the law wishes something, it states it; if the law does not wish something, it is silent upon it). The materiality of the breach is a threshold, implying that suspension (or termination) is simply not allowed for non-material breaches. It should be kept in mind that the subject matter of VCLT Article 60 is only the faculty to suspend (or terminate) the treaty. VCLT Article 42(2) for its part clearly states that suspension is not permitted, except when authorized by the Convention itself, and therefore discourages recourse to the default rule whereby "rules of customary international law will continue to govern questions not regulated by the [VCLT]". ${ }^{56}$

In other words, the VCLT does not prevent the application of rules on responsibility (even for minor breaches), but it clearly excludes the application of external rules justifying a treaty suspension that would not be justified under the Convention. Non-material breaches do trigger legal consequences as to the responsibility of the breaching state, but cannot entitle the other party to suspend the treaty.

This specification (no gap exists in the VCLT that corresponds with minor violations) is of paramount importance in the examination of Greece's exceptio argument. If a gap existed, the exceptio could seem applicable ratione materiae

\footnotetext{
${ }^{55}$ This does not prevent Simma and Tams, in their commentary of VCLT Art. 60 to note that "[t]he idea underlying Article 60 is the principle inadimplenti non est adimplendum": B. Simma and C. J. Tams, 'Article 60, Convention of 1969', in O. Corten and P. Klein (eds), The Vienna Conventions on the Law of Treaties: A Commentary (OUP, 2011), Vol II, 1351, at 1353. The silence about non-material breaches is noted but is not sufficient to alter the equation: VCLT Art. 60 is the exceptio.

${ }^{56}$ VCLT Preamble, final sentence.
} 
to minor breaches. Thus, it surely would not be enough (as Judge Simma cryptically indicates ${ }^{57}$ ) to rely on Greece's characterization of FYROM's breach as "material" to solve the issue and escape the exceptio. Emphatic statements by parties should not be relied upon uncritically, especially in the circumstances at hand, where FYROM's alleged violations, if anything, appeared to be less than material. If a gap in the law of treaties actually existed (quod non), Greece could in principle invoke the exceptio to react to minor breaches, and certainly would not lose this capacity merely for having overstressed FYROM's misconduct in its pleadings in an attempt to secure other remedies (i.e. counter-measures and suspension).

\section{The exceptio general principle may exist, but could not assist Greece}

Initially, Greece stated that is was uninterested in the suspension of the IA, ${ }^{58}$ but then changed its mind at the hearings. ${ }^{59}$ This hesitation was possibly due to the fact that FYROM's alleged breaches of the Accord seemed inconsequential, thus falling short of engaging VCLT Article 60. Revealingly, Greece also maintained that its non-performance was lawful not so much because that the IA had been suspended, but because a previous breach of the same instrument occurred. As noted above, however, the ARSIWA regulate this hypothesis thoroughly, and there is no need to or possibility of recourse to general principles of contractual law to displace their application.

The exceptio might still apply in cases where the ARSIWA provisions on counter-measures do not apply (e.g. in the implementation of contracts stipulated with a government or an international organization, when national rules are referred to by international law, for instance in certain bilateral investment treaties; ${ }^{60}$ or when the ARSIWA are contracted out of by virtue of a lex specialis under ARSIWA Article 55). Theoretically, the exceptio could help in

\footnotetext{
${ }^{57}$ Application of the Interim Accord, supra note 2, para. 22.

${ }^{58}$ Counter-Memorial, para. 8.2, available at <http://www.icjcij.org/docket/files/142/16356.pdf> [last accessed 1 May 2012]; Rejoinder, para. 8.3, available at <http://www.icj-cij.org/docket/files/142/16360.pdf> [last accessed 1 May 2012].

${ }^{59}$ Application of the Interim Accord, supra note 2, paras. 118-19.

${ }^{60}$ For an instance, see Klöckner Industrie-Anlagen GmbH v Republic of Cameroon, (1983) 2 ICSID Reports 9 (Award, 21 October 1983), and J. Paulsson, 'The ICSID Klöckner v Cameroon Award: The Duties of Partners in North-South Economic Development Agreements', (1984) 1 JIArb 145. See also Klöckner Industrie-Anlagen GmbH v Republic of Cameroon, (1986) 2 ICSID Reports 95 (Decision on Annulment, 3 May 1985).
} 
identifying the conditions of suspension of a treaty to which the VCLT does not apply (for instance, treaties pre-dating the VCLT's entry into force), but most likely the materiality requirement for suspension has ripened into custom and applies regardless. ${ }^{61}$ Nevertheless, as far as the IA is concerned, the exceptio could not apply directly, as other norms have priority regarding the possibility both to suspend the treaty and to withhold performance in response to a prior breach.

As noted above, the ICJ dismissed the exceptio because Greece's pleading had no merit on the facts (the defendant could not demonstrate that the factual requirements for its application existed). Consequently, the Court did not consider whether Greece's defence was faulty on the law. Reading the pleadings of the parties and the compte-rendus of the hearings, one has the impression that the central issue was the existence (vel non) of the principle: the excerpt from Anzilotti's 1937 Opinion $^{62}$ was alternately glorified or denigrated precisely to support or refute the existence and effectiveness of this principle. Even Judge Simma's concern, in his Opinion, seems to prove that the exceptio does not have "a right of place in international law".

Arguably, the controversy about the status of the principle would not have been an easy one to solve, and it is not surprising that the Court chose not to embark upon it. To establish or discard the existence of the principle requires considerable comparative effort and some judicial discretion, complicated by the inherent difficulty of transplanting a contract law principle, as is, into the regime of treaty obligations. By contrast, the question of the applicability of the principle was fairly easy to analyse (and discard), even arguendo, in the way proposed above: a few additional paragraphs would not curtail the Court's desire for judicial economy, but could have made a considerable contribution to the clarification of general principles' role in the system of international law sources. It would have sufficed to portray Greece's argument as an attempt to turn lex specialis on its head: whether the exceptio exists or not, it is arduous to contend convincingly that lex generalis derogat legi speciali. The Court could have

\footnotetext{
${ }^{61}$ Application of the Interim Accord, supra note 2, para. 29. Note that in Legal Consequences for States of the Continued Presence of South Africa in Namibia (South West Africa) notwithstanding Security Council Resolution 276 (1970), Advisory Opinion, ICJ Reports 1971, p. 16, at 46-7, para. 94, the Court simply noted that the rules on termination of VCLT Art. 60 "may in many respects be considered" of customary nature. On the customary content of VCLT Art. 60(1), see M. E. Villiger's Commentary on the 1969 Vienna Convention on the Law of Treaties (Martinus Nijhoff, 2009), at 749-50.

${ }^{62}$ Emphatically describing the exceptio as a general principle under Art. 38(3) of the PCIJ Statute, see Diversion of Water from Meuse (Netherlands v Belgium), PCIJ Report Series A/B No 70, at 50 (Anzilotti, dissenting). See also ibid., at 77 (Hudson).
} 
addressed Greece's attempt to misuse the exceptio principle without abusing its judicial function, and, in the process, done a wider service to international law by emphasising that principles must be taken seriously. As noted by Judge Cançado Trindade:

The Hague Court, also known as the World Court, is not simply the International Court of Law, it is the International Court of Justice, and, as such, it cannot overlook principles. ${ }^{63}$

${ }^{63}$ Pulp Mills, supra note 39, para. 220 (Judge Cançado Trindade) (emphasis in the original). 